\title{
Granular cell myoblastoma of the oesophagus
}

\author{
GORDON L. LARSEN ${ }^{1}$, RAYMONDG. ARMSTRONG, \\ WILLIAM STANFORD, and ROBERT E. CLINE

\begin{abstract}
Thoracic Surgery Service, Department of Surgery, Wilford Hall United States Air Force Medical Center
\end{abstract} \\ (AFSC), Lackland Air Force Base, Texas 78236, USA
}

\begin{abstract}
Larsen, G. L., Armstrong, R. G., Stanford, W., and Cline, R. E. (1973). Thorax, 28, 641-643. Granular cell myoblastoma of the oesophagus. During evaluation of symptoms of oesophageal reflux in a 40-year-old man, a filling defect of the distal oesophagus was seen on the oesophagogram, and this was noted to be a submucosal mass at oesophagoscopy. He also had an oesophageal hiatus hernia. The lesion proved to be a granular cell myoblastoma, a rarity in the oesophagus, only 11 previous cases having been reported. Symptomatology evaluation and management of granular cell myoblastoma of the oesophagus are discussed. As with other submucosal lesions of the oesophagus, preoperative biopsy through an intact mucosa is to be avoided because of danger to the patient from haemorrhage or perforation and subsequent inflammatory reaction making surgical resection and microscopic diagnosis difficult.
\end{abstract}

Over $50 \%$ of reported cases of granular cell myoblastoma occur in the skin, muscle, and breast. Occurrence in the respiratory tract, genitourinary tract, retroperitoneum, and gastrointestinal tract is relatively rare (Stout and Lattes, 1967). Therefore, when we encountered a case of granular cell myoblastoma of the oesophagus, incidental to an evaluation for hiatal hernia, we were stimulated to review the pertinent medical literature and discovered 11 other cases (Abrikossoff, 1931; Crawford and DeBakey, 1953 ; DeGouveia et al., 1960; Obiditsch-Mayer and Salzer-Kuntschik, 1961; Rella, Conte, and Farrell, 1963; Keshishian and Alford, 1964 ; Stout and Lattes, 1967 ; Wypkema, Schmaman, and Berson, 1967; Flege and Edmonds, 1969; Paskin, Hull, and Cookson, 1972) including the first report of such a lesion by Abrikossoff in 1931. In this paper our case is desscribed, the previously reported cases are reviewed, and the surgical management is discussed.

\section{CASE REPORT}

A 40-year-old Caucasian man presented with symptoms of oesophageal reflux. An oesophagogram demonstrated a small sliding oesophageal hiatus and a smooth $1 \mathrm{~cm}$ filling defect in the distal oesophagus (Fig. 1). At oesophagoscopy the latter was seen to be a yellowish

1 Reprint requests to : Colonel Gordon L. Larsen (SGHST), Wilford Hall USAF Medical Center, Lackland AFB, Texas 78236 submusocal lesion $37 \mathrm{~cm}$ from the incisors and $1 \mathrm{~cm}$ proximal to the oesophagogastric junction. The lesion was thought to be a leiomyoma. Mild oesophagitis was noted over the distal $10 \mathrm{~cm}$ of the oesophagus. The hiatus hernia was corrected transthoracically using a Belsey Mark IV repair. The submucosal lesion was removed without entering the oesophageal lumen. The final histological diagnosis of the lesion was granular cell myoblastoma (Fig. 2). Two years postoperatively the patient was asymptomatic and the oesophagogram showed no evidence of the hernia or abnormality of the oesophageal mucosa.

T A B LE

AGE, SEX, AND TUMOUR SITE IN 12 CASES OF GRANULAR CELL MYOBLASTOMA OF THE OESOPHAGUS

\begin{tabular}{|c|c|c|c|}
\hline Author & Age & Sex & Site of Tumour \\
\hline $\begin{array}{l}\text { Abrikossoff } \\
\text { DeGouveia et al. } \\
\text { Rella et al. } \\
\text { Wypkema } \text { et al. }\end{array}$ & $\begin{array}{l}29 \\
19 \\
43 \\
49\end{array}$ & $\begin{array}{l}\mathbf{F} \\
\mathbf{F} \\
\mathbf{F}\end{array}$ & $\begin{array}{l}\text { Upper oesophagus } \\
\text { Upper oesophagus } \\
\text { Upper oesophagus } \\
\text { Distal oesophagus }\end{array}$ \\
\hline $\begin{array}{l}\text { Flege and Edmonds } \\
\text { Larsen and }\end{array}$ & $\begin{array}{l}43 \\
40 \\
40\end{array}$ & $\begin{array}{l}\mathbf{F} \\
\mathbf{M}\end{array}$ & $\begin{array}{l}\text { Upper oesophagus } \\
\text { Distal oesophagus } \\
\text { Distal oesophagus }\end{array}$ \\
\hline $\begin{array}{l}\text { Armstrong } \\
\text { Crawford and } \\
\text { DeBakey }\end{array}$ & 31 & $\mathbf{F}$ & $\begin{array}{l}\text { Upper oesophagus, uterus, } \\
\text { ovaries, salpinges, and skin }\end{array}$ \\
\hline $\begin{array}{l}\text { Stout and Lattes } \\
\text { Keshishian and }\end{array}$ & $\stackrel{?}{48}$ & $\stackrel{?}{\mathbf{F}}$ & $\begin{array}{l}\text { Distal oesophagus and stomach } \\
\text { Upper oesophagus, posterior }\end{array}$ \\
\hline $\begin{array}{l}\text { Obiditsch-Mayer } \\
\text { and Slazer- } \\
\text { Kuntschik }\end{array}$ & 28 & $\mathbf{F}$ & Upper oesophagus and trachea \\
\hline Paskin et al. & ? & ? & $\begin{array}{l}\text { Mid-oesophagus and bronchus } \\
\text { intermedius }\end{array}$ \\
\hline
\end{tabular}




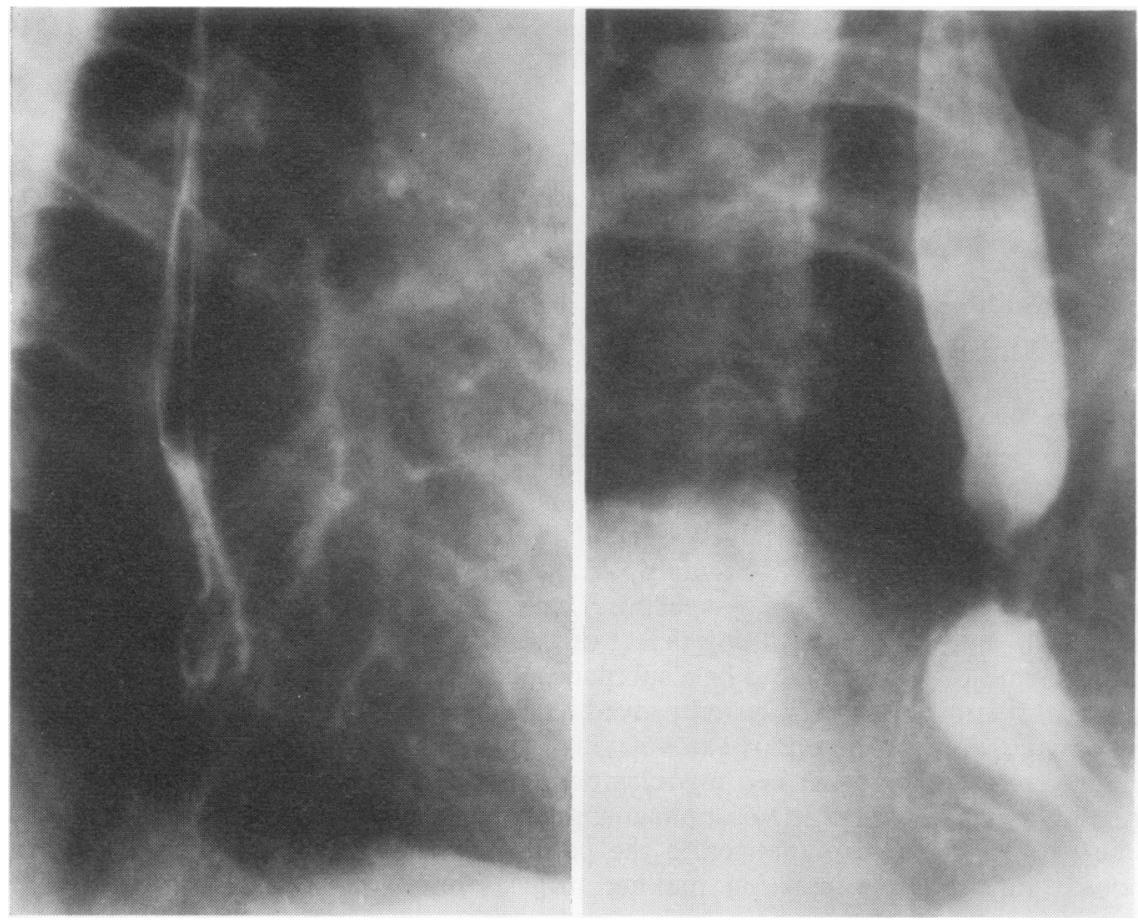

FIG. 1. (left) Smooth elevated $1 \mathrm{~cm}$. lesion of the distal oesophagus. (Right) Oesophagogram showing small sliding hiatal hernia.

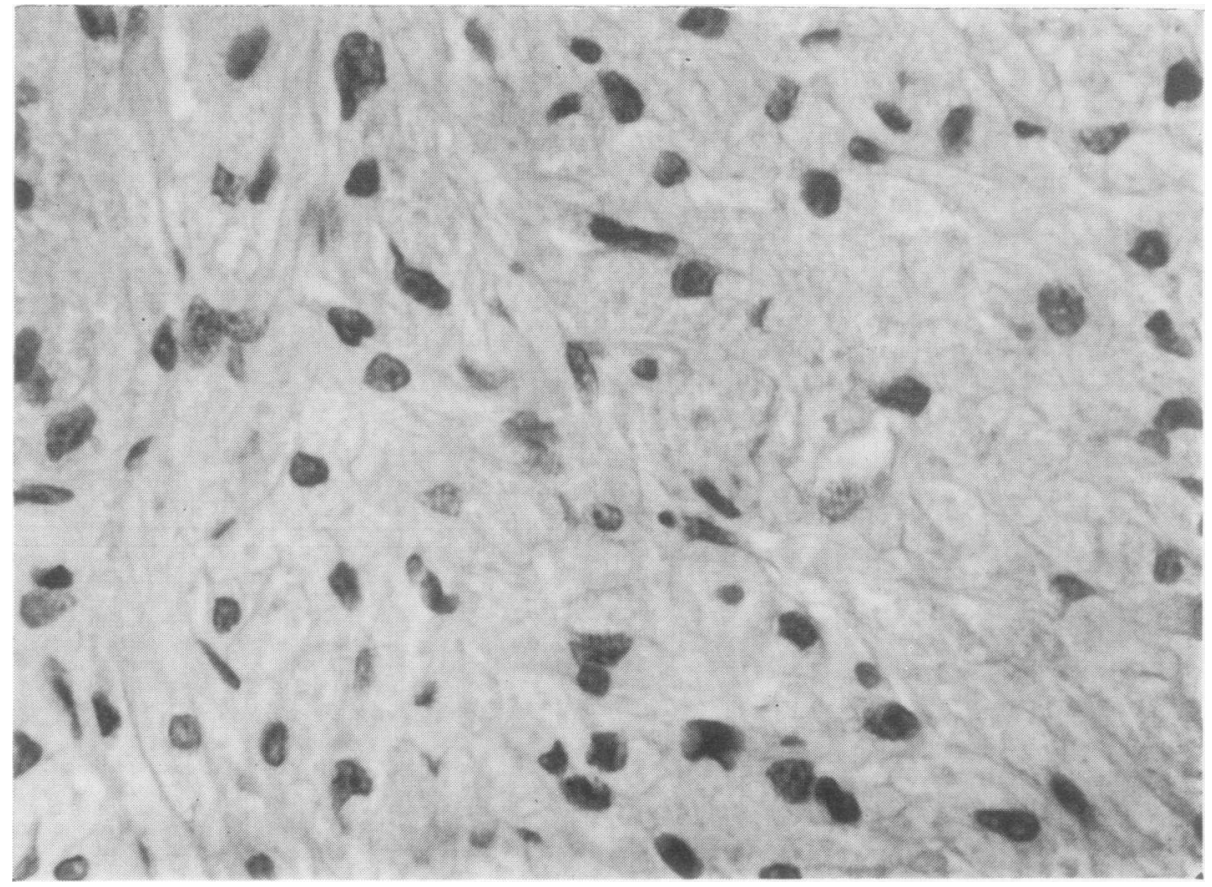

FIG. 2. High-power photomicrograph of the tumour showing large cells with small nuclei. The cells are moulded into various sizes and shapes. (Haematoxylin and eosin $\times 260$ ) 


\section{DISCUSSION}

Of the 12 cases thus far recorded, including the present report, eight were in women, two were in men and in two the sex was not specified. Seven were in the upper third of the oesophagus, four in the distal third, and one in the middle third (Table).

The mode of clinical presentation was not always specified. Some tumours were asymptomatic and discovered incidentally at necropsy or found during evaluation of unrelated symptoms, as in the case herein reported. At least three in the cervical oesophagus were large and produced dysphagia. Those tumours evaluated ante mortem revealed a filling defect on the oesophagogram and were seen as a submucosal lesion at oesophagoscopy. This presentation is similar to that of the much more common oesophageal leiomyoma.

The rare malignant granular cell myoblastoma is known under different names, including malignant organoid granular cell myoblastoma and alveolar soft part sarcoma (Stout and Lattes, 1967). Of the cases reviewed, the possibility of malignancy was raised in that reported by Obiditsch-Mayer and Salzer-Kuntschik (1961) of a 28-year-old woman with granular cell myoblastoma of the oesophagus and lymph node metastases. Unfortunately she died following a tracheostomy so that the clinical aggressiveness of the tumour could not be determined. Crawford and DeBakey (1953) reported a case with local peri-oesophageal invasion and yet the patient survived 22 years despite incomplete resection.

The diagnosis of these lesions must be based on histological study of the tissue ; however, preoperative diagnosis is not necessary. Indeed, as in all intramural lesions with intact, overlying mucosa, biopsy should be avoided because of the danger of perforation or haemorrhage, and because biopsy may produce sufficient inflammatory reaction to make subsequent surgical enucleation impossible (Gibbon, Sabiston, and Spencer, 1969). Furthermore, if biopsy is performed, it is well to remember that these lesions may stimulate the epithelial cells to proliferate downward for a short distance, form keratinized pearls, and superficially imitate squamous cell carcinoma (Stout and Lattes, 1967).

Thus we feel that the proper surgical management of these rare lesions is similar to that for leiomyomas of the oesophagus. Preoperative tissue diagnosis being unnecessary, one should avoid the danger of biopsy and allow the mucosa to remain intact. At operation the lesion shells out easily without entry into the oesophageal lumen. This approach, following sound surgical principles, ensures the greatest safety for the patient and the easiest technical procedure for the surgeon.

\section{REFERENCES}

Abrikossoff, A. I. (1931). Weitere Untersuchungen über Myoblastenmyome. Virchows Archiv für pathologische Anatomie und Physiologie und für klinische Medizin, 280, 723.

Crawford, E. S., and DeBakey, M. E. (1953). Granular-cell myoblastoma - two unusual cases. Cancer, 6, 786.

DeGouveia, O. F., Pereira, A. A., Netto, M. B., Vilhena, A. M., Dutra, G., and Bryk, D. (1960). Granular cell myoblastoma of the esophagus (Abrikossoff's tumor). Gastroenterology, 38, 805.

Flege, J. B., Jr., and Edmonds, T. T. (1969). Granular cell myoblastoma of the esophagus. A case report. Journal of Thoracacic and Cardiovascular Surgery, 58, 217.

Gibbon, J. H., Jr., Sabiston, D. C., and Spencer, F. C. (1969). Surgery of the Chest, 2nd ed., W. B. Saunders, Philadelphia.

Keshishian, J. M., and Alford, T. C. (1964). Granular cell myoblastoma of the esophagus. Report of a case. American Surgeon, 30, 263.

Obiditsch-Mayer, I., and Salzer-Kuntschik, M. (1961). Malignes, "gekorntzelliges Neurom" sogenanntes "Myoblastenmyom" des Oesophagus. Beiträge zur pathologischen Anatomie und zur allgemeinen Pathologie, $125,357$.

Paskin, D. L., Hull, J. D., and Cookson, P. J. (1972). Granular cell myoblastoma: A comprehensive review of 15 years experience. Annals of Surgery, 175, 501.

Rella, A. J., Conte, A. J., and Farrell, J. T. (1963). Granular cell myoblastoma of the esophagus. A case report. Archives of Otolaryngology, 78, 715.

Stout, A. P., and Lattes, R. (1967). Atlas of Tumor Pathology, 2nd ser.: Fascicle 1. Tumors of the Soft Tissue, p. 92. Washington, D.C.

Wypkema, W., Schmaman, A., and Berson, D. (1967). Granular cell myoblastoma of the oesophagus. A report of two cases. South Africa Medical Journal, 41, 911. 